\title{
sobre: La doble rendija. Autofiguraciones científicas de la literatura en el Río de la Plata, de Luciana Martinez. Buenos Aires:
}

\author{
Prometeo, 2019
}

\author{
BRUNO GROSSI Universidad Nacional del Litoral - CONICET, Argentina \\ ORCID 0000-0001-7243-7613 \\ brunomilang@gmail.com
}

En un punto cúlmine de Contacto (1997) de Robert Zemeckis, la astronauta interpretada por Jodie Foster da la vuelta a la galaxia para intentar entrar en contacto con vida extraterrestre. Una vez que la nave atraviesa las turbulencias y divisa el supuesto planeta de destino, azorada por la imagen deslumbrante que se presenta ante sí, consigue decir entre balbuceos: «No tengo palabras. No tengo palabras... para describirlo. Poesía. Deberían haber mandado... un poeta. Es hermosísimo. Qué hermoso. Es tan hermoso. Yo no tenía idea». Una vez en la tierra su experiencia intensa y transfiguradora es confrontada por una triste realidad: el viaje que para ella se extendió durante horas, desde el punto de vista de la tierra no pasó de unos pocos segundos. El viaje, le aseguran, nunca tuvo lugar. Ante la imposibilidad de aportar pruebas tangibles, un tribunal de las fuerzas armadas (comandado por el siempre despiadado James Wood) intenta arrebatarle una confesión de lo que ellos entienden no es más que una mera fabulación subjetiva. Es que en definitiva el carácter esotérico y aparentemente inútil de los saberes que Foster esgrime no hace sino invalidar su experiencia singular frente a los demás. De allí que lo que comienza como una entrevista para aclarar los términos del viaje espacial termina por convertirse en una impugnación inadvertida y lapidaria inclusive del propio Einstein. De pronto todo el edificio de las ciencias más avanzadas se vuelve, frente al sentido común férreamente empirista de los militares, algo tan endeble que parece confundirse con la creencia religiosa más desquiciada.

La tensión latente (y fascinante) entre arte, ciencia y religión que el film esboza es lo que $L a$ doble rendija. Autofiguraciones científicas de la literatura en el Río de la Plata no hace sino desplegar teóricamente en nuestro contexto latinoamericano a partir de los textos de los escritores Mario Levrero y Marcelo Cohen. El libro de Martinez parte de una constatación: los avances de la física cuántica obligan a repensar cómo el saber científico constituido a partir de la física clásica de corte newtoniana se convirtió en el único modo válido de producción de conocimiento. El concepto de materia, la relación sujeto-objeto, el lugar dado a la imaginación (12-13-14) comienzan a ser seriamente revisados desde el momento que los padres de la cuántica afirman

Para citar este artículo: Grossi, B. (2020). Sobre: La doble rendija. Autofiguraciones científicas de la literatura en el Río de la Plata, de Luciana Martinez. El taco en la brea, 12 (junio-noviembre). Santa Fe, Argentina: UNL. eoo2o DOI: 10.14409/tb.v1i12.9698 
-a partir por ejemplo del principio de incertidumbre- que lo único real pasible de ser conocido es aquello que es determinado por el observador, tal como se colige del famoso experimento de la doble rendija que le da título al libro. Pero más allá de su radicalidad teórica, la así llamada Interpretación de Copenhague se desentiende en cierto sentido de las implicancias filosóficas de sus hipótesis, en tanto un pensamiento consecuente con dicha lógica obligaría nada más ni nada más que a un nuevo modelo de construcción de la realidad (30). De allí que toda una sensibilidad cuántica avant la lettre (14) que va de la mística renana al romanticismo inglés, pasando por el budismo hasta las ficciones especulativas borgeanas, se vuelven objeto de una luz renovada: los saberes difusos de ayer se vuelven de pronto extrañamente visionarios. Es lo que lleva a la literatura reclamar sus derechos, hacer valer su pulsión gnoseológica y afirmar las bases compartidas con la ciencia (señalar cómo las «dos culturas» se separaron progresivamente es otro motivo subyacente del libro). Las ontologías singulares y subjetivas de la ficción parecieran ser por lo tanto las más adecuadas para darnos imágenes que nos permitan asimilar cultural y psicológicamente la existencia dinámica, discontinua e inasible del universo postulado por la cuántica (34). Sin embargo, la literatura no es —en la hipótesis de Martinez- una mera subsidiaria de la ciencia, un discurso que proveería de metáforas bonitas a las áridas formulaciones de la otra y que solo entraría en diálogo como un modo de legitimarse a sí misma, sino que por el contrario pelea cuerpo a cuerpo con ella en la fundación ontológica del universo compartido (24).

Es por ello que, aunque Martinez no niegue el encanto intrínseco de la ciencia ficción y su capacidad de imaginar mundos, su planteo parece querer rebasar lo que de improductivas tienen esas concepciones genéricas y afirmar, ambiciosamente, la condición realista de lo que otrora era considerado como fantástico o delirante. De allí que se tome muy en serio la ficcionalización que la literatura realiza sobre los saberes científicos, adentrándose por lo tanto en un universo que se mantenía oscuro e inexplorado para la crítica especializada. Es lo que ocurre al interrogar las máximas de la parapsicología y la termodinámica que Levrero utiliza para interrogar los fenómenos subjetivos: de pronto términos abstrusos como «mancia», «telergía» o «espíritu» que aparecían en su obra y que leíamos con una mezcla de sorna e incredulidad, se nos vuelven conceptos densos que permiten vislumbrar mejor la lucha apasionante de fuerzas que ocurren en los textos del uruguayo, en las que la necesidad de equilibrio energético para la vida diaria y la búsqueda desgarradora de un Absoluto suprasensible entran en tensión en el espacio mismo de la escritura (134). Algo similar ocurre con la lectura de Cohen. Las referencias extemporáneas al budismo y las tesis sociológicas más actuales que sus novelas exhiben de forma desconcertante demandan un dispositivo crítico que, lejos de despejar los términos heterogéneos del problema, puedan hacerlas coexistir sin domesticarlos o reducirlos una a la otra. Es lo que hace Martínez y lo que le permite leer en el leit motiv del desapego oriental del yo (respecto de los lugares comunes de la cultura) una forma de imaginar nuevas comunidades ajenas a los mecanismos de control del Mercado y el Estado. En suma: ontologías subjetivas de corte cuántico que exceden nuestra reducida visión cultural, heredera de los paradigmas atomistas, a partir de la cual se acostumbra a considerar lo subjetivo en términos de personalismos aislados (200).

La excentricidad del libro no solo radica en lo insólito de los asuntos tratados, sino también en el modo de afrontarlos, en la consciencia de la enunciación ensayística como condición indispensable para alcanzar el saber. Es que, en cierto sentido, si «el sabio investigador habla desde 
fuera, tal como lo hace un anatomista del cerebro» decía Bataille (36),' es decir estableciendo una distancia segura que lo preserva del encuentro con aquello que puede a su vez transformarlo, Martínez por el contrario realiza la experiencia singular de las obras, se mimetiza con los saberes bizarros que los textos exponen, sigue los movimientos contradictorios que ninguna enunciación científica puede capturar. Esa decisión, claro, no está exenta de peligros: el verdadero ensayista no teme pasar por un irracionalista, un místico o un idiota para que la verdad de la experiencia de la obra se revele. La verdad de Levrero y Cohen, la posibilidad de pensar un sujeto por venir y mundos-en-común nuevos depende por lo tanto de una escritura, de un tipo de exposición que permita hacer sensible aquello que excede lo positivo, inmediatamente dado, que exprese - y allí radica toda la ironía, la gracia del asunto - lo que no deja sin embargo de sustraerse en la materia. Es lo que Martínez persigue incansable y felizmente durante todo el libro: decir la experiencia desbordante que Jodie Foster, en el medio del espacio, con sus pobres medios discursivos, no hacía sino apenas rozar.

\section{Nota}

1 Bataille, G. (1957). El erotismo. Madrid: Tusquets, 2009. 